\title{
The Development of Physics Learning Materials to Improve Students' Learning Results
}

\author{
Muhammad Syahrul Kahar (*), Miftah Sigit Rahmawati \\ Universitas Muhammadiyah Sorong, Jalan Pendidikan No. 27 Kota Sorong, Indonesia
}

\begin{abstract}
Received: September 04, 2019
Revised: February 26, 2020

\section{Abstract}

Teaching science should emphasize the provision of real experiences for students to develop their competence so that their ability in learning can be improved. The aimed of this study was to evaluate the improvement of students' learning result after the development of the teaching materials. This study used the Research and Development (R\&D) approach with the 4D model. The data were collected through test and validation analysis. The findings showed that after implementing the developed material, there were no students in the low category, students in the medium level were $11(35,48 \%)$ only, while the majority of them (20 students) which were $64,52 \%$ were categorized into the high level. Besides that, referring to the descriptive analysis of mean scores obtained by students, their achievement was regarded to be better than before $(87,06)$. In terms of the improvement in students' learning results, after they were taught using the media which was developed in this study, students experienced improvement as the t-test showed the $\mathrm{t}_{\text {count }}=50,160>\mathrm{t}_{\text {table }}=2,042$ with the significance level of 0,000 . Based on that results, the development of teaching material did support the learning activities in the classroom. Therefore, it can be concluded that the use of teaching material brought an impact on the improvement of students' learning results so that they can understand the materials better. This current study gave insight to the learners about the importance to develop teaching media for learning Physics.
\end{abstract}

Keywords: Physics Learning, Learning Results, Teaching Materials

How to Cite: Kahar, M.S., Rahmawati, M.S. (2020). Pengembangan bahan ajar pembelajaran fisika terhadap peningkatan hasil belajar fisika. Formatif: Jurnal Ilmiah Pendidikan MIPA, 10 (1): 57-66. http://dx.doi.org/10.30998/formatif.v10i1.4621

\section{INTRODUCTION}

Teaching science puts emphasis on giving real experiences to students by utilizing strategies that can boost their motivation to improve their activeness in learning activities (Alina, et al. 2016). University students tend to not enjoying physics subjects considering that it is identic with formulas, memorization, and calculation. That is why students prefer non-exact subjects that only require them to read. On the other hand, students need a reward to support their learning achievement (Soenarno, 2019).

Based on the observation which was initially performed, many students did not pay attention to the subjects being taught, were not active to explore the materials more, and had no motivation to study. Interviews conducted to some students to investigate their habits during the Physics class indicated that most of them felt bored to study and did not enjoy the subject. Therefore, according to Toheri \& Azis (2012), to increase the students' interest to learn, it is necessary to develop teaching materials and media to motivate them to study, to be more active in the class, and to more enjoy the subject. Besides the delivery 
of the right materials, other relevant models should be implemented to support the effectiveness of learning.

Besides that, Wulansari (2014) states that the teaching method is highly necessary to stimulate students to improve their learning activities and outputs. Also, Masitoh \& Prabawanto (2016) explain that explorative learning can lead the class to be more attractive so that the students' learning results, motivation, and activities in the classroom can be better. This learning process should be carried out using materials orienting on the problemsolving to facilitate students to be more active. Some earlier studies have concluded that it is important to develop teaching materials to assist students to understand the subject. Based on the problem, it is important to provide explorative learning to assist students in mastering the material so that the learning output can be more optimally achieved. This learning process was then implemented using teaching material to support the learning of Physics.

Sinuraya et al. (2018) argues that the improvement of students' learning results is highly affected by the selection of modules or learning materials and worksheets but not related to the students' learning style. Related to the problems presented above, the aim of this study was to evaluate the improvement of students' learning results after the development of Physics Learning Materials.

\section{METHODS}

This study employed Research and Development approach and developed the implementation of the model using True Experimental. This research used pretest - posttest control group design. The development procedure has four stages including (1) preliminary study, (2) planning, (3) development, and (4) implementation as illustrated in the figure 1.

This study was carried out in the Informatics Department, Physics Class. The research subjects were 31 students of Physics A class, Informatics Department in the second semester, the academic year of 2018/2019 selected using a proportionate stratified random sampling technique. Before the teaching material delivered, expert validation was performed using a feasibility assessment rubric as the instruments. It contains some indicators including (1) teaching material format, (2) contents, (3) Language and presentation, and (4) Benefits. The validity criteria are modified from (Hobri, 2009) as follows:

$$
\begin{aligned}
& 1 \leq \mathrm{va}<2 \text { not valid } \\
& 2 \leq \mathrm{va}<3 \text { quite valid } \\
& 3 \leq \mathrm{va}<4 \text { valid }
\end{aligned}
$$

Annotation: $\mathrm{Va}=$ the average of experts' assessment

The product will be regarded to be valid when the mean of Va is higher than 3 . In contrast, if it is lower than 3 , the developed teaching materials are not valid yet. Therefore, revision is needed. The instrument which was used for the hypothesis analysis was the learning result test. The test was performed through two stages, pretest, and posttest. The data were analyzed using descriptive statistical analysis to describe the distribution characteristics of the Physics learning result scores using SPSS 20.

The test performed on the hypothesis aimed at answering the proposed hypothesis. It used two - tail test as follows (Sugiyono, 2008).

$$
t_{\text {count }}=\frac{\bar{x}_{1}-\bar{x}_{2}}{S \sqrt{\left(\frac{1}{n_{1}}+\frac{1}{n_{2}}\right)}} \quad S^{2}=\frac{\left(n_{1}-1\right) S_{1}{ }^{2}+\left(n_{2}-1\right) S_{2}{ }^{2}}{n_{1}+n_{2}-2}
$$


Annotations:

$\bar{x}_{1}=$ mean score of experimental class

$\bar{x}_{2}=$ mean score of the control class

$S_{1}=$ standard deviation of experimental class

$S_{2}=$ standard deviation of the control class

$n_{1}=$ the number of samples in the experimental class

$n_{2}=$ the number of samples in the control class

The research hypothesis that would be tested is presented below:

$\mathrm{H}_{0} \quad: \mu_{1}=\mu_{2}$

$\mathrm{H}_{\mathrm{a}} \quad: \mu_{1} \neq \mu_{2}$

Hypothesis null (Ho) states that there is no improvement in students' learning results after taught using the developed teaching materials. While the alternative hypothesis (Ha) proposes that there is a significant improvement in students' learning outputs as the result of the teaching materials developed in the current study.

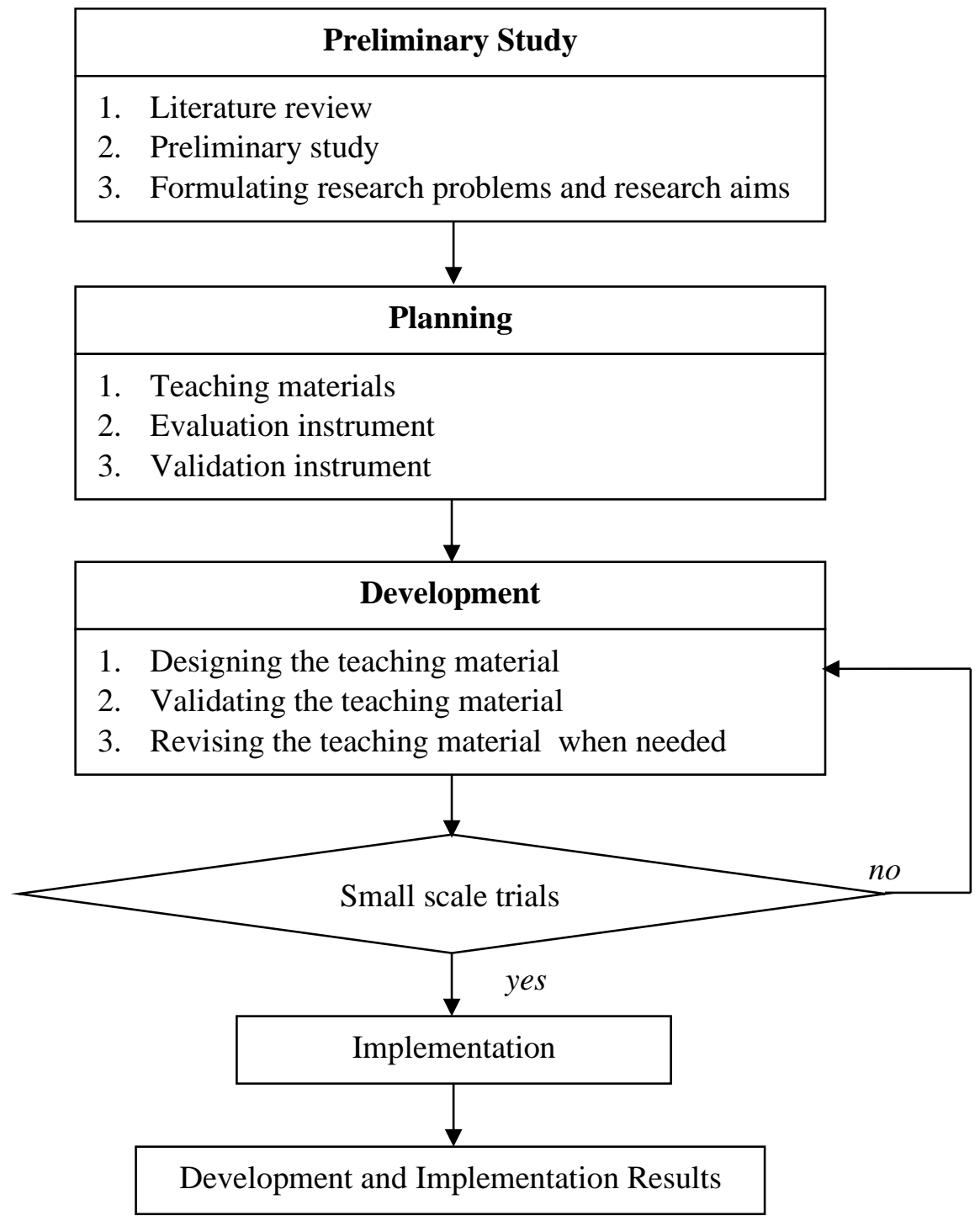

Figure 1. Design of Development 


\section{RESULTS \& DISCUSSION}

\section{Results}

The initial product developed in this study was the teaching material that was taught in the Informatics Engineering Department. Prior to that, it was validated by some experts related to the subject. Also, the evaluation sheet in the form of a questionnaire was designed. It contains some assessment aspects, suggestions, and comments from the experts. The results of the evaluation included the scores of teaching material quality using the scales from 1 to 4 . The research product which is, in this case, the teaching material has got inputs from the experts so that its quality was improved and attained its set goals. The assessment items included format, content/ substance, language and presentation, and aims/ purposes. The experts assessing the student worksheet which was also developed in this study were; (1) Rahmatullah Bin Arsyad, S.Pd., M.Pd (Lecturer of FKIP Universitas Muhammadiyah Sorong, focusing on the content / substance); (2) Muhammad Fathurrahman, S.Pd., M.Pd (Lecturer of FKIP Universitas Muhammadiyah Sorong focusing on Media). The teaching material is presented in Figure 2.

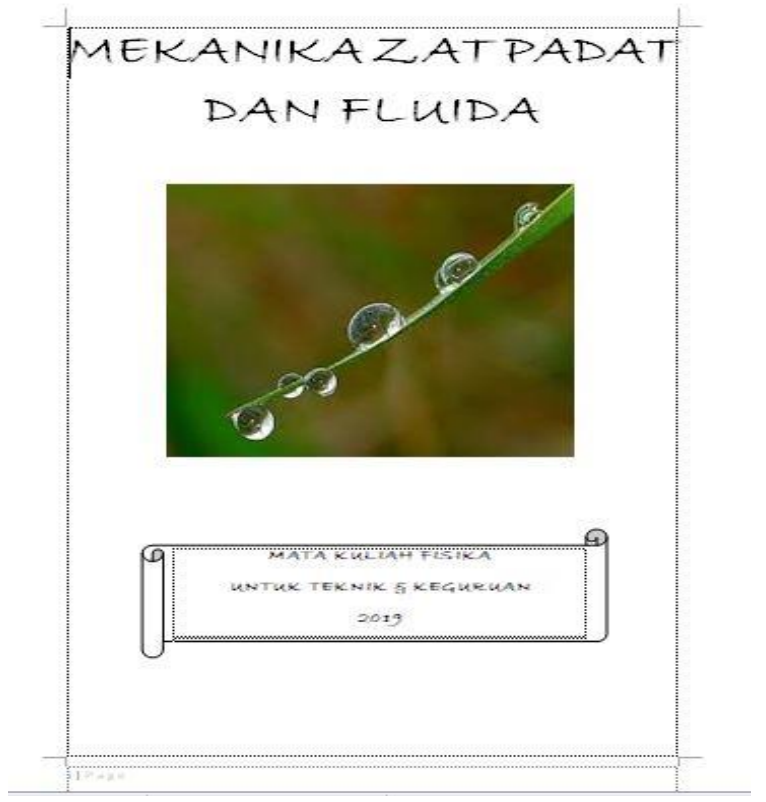

Figure 2. Teaching Material

Data that are presented in the diagram below are the results of the assessment on the product performed by experts. The presentation has aims to show the quality of the product which was developed. 


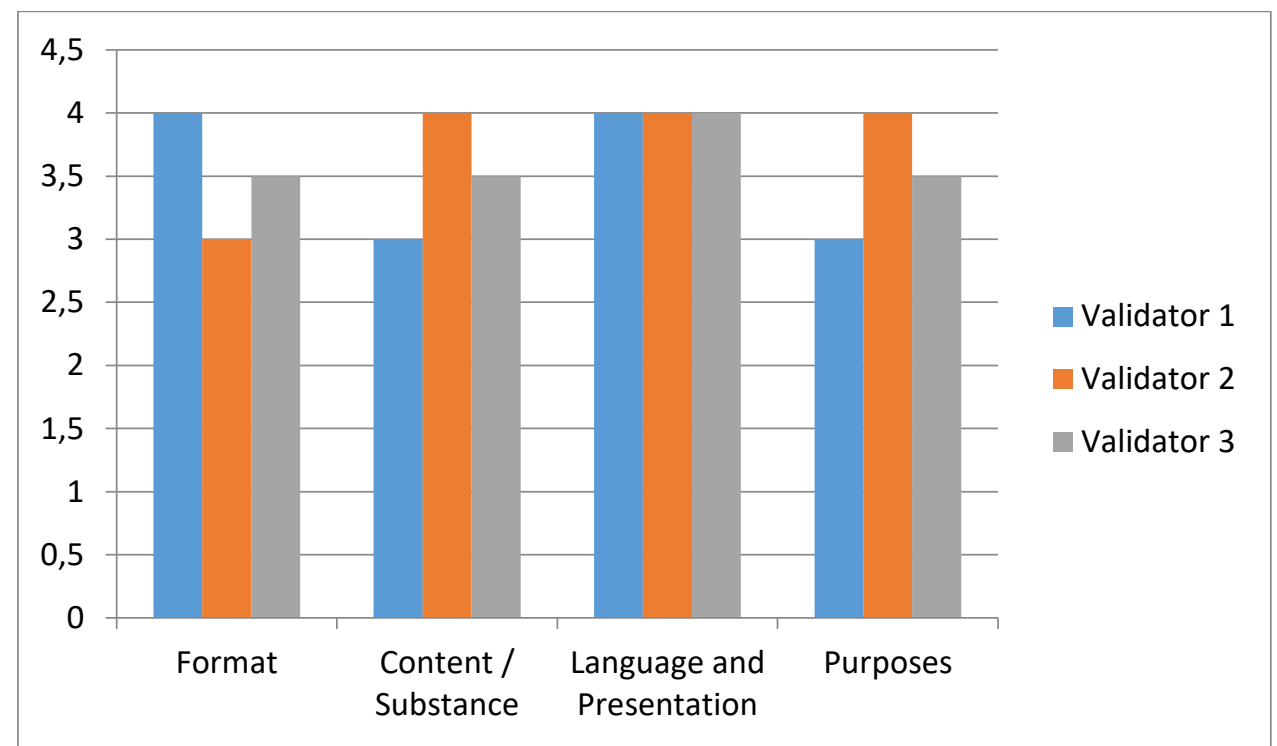

Figure 3. Data of Teaching Material Validation

Based on scores of the assessment carried out by experts, the teaching material which was developed can be regarded to be Good. It is proven by the average score given by the experts was in the Good category. Therefore, it could be concluded that the Physics Teaching material can be used in each trial that would be performed. Following is the presentation of descriptive test on students' learning results (Table 1).

Table 1. Descriptive Analysis of Learning Result Scores

\begin{tabular}{lll}
\hline \multicolumn{1}{c}{ Score } & \multicolumn{2}{c}{ Experimental } \\
& Pretest & Posttest \\
\hline The number of students & 31 & 31 \\
Average score & 53,61 & 87,06 \\
Minimum score & 20,00 & 67,00 \\
Standard Deviation & 11,28 & 9,66 \\
Maximum score & 67,00 & 100,00 \\
Variance & 127,24 & 93,39 \\
\hline
\end{tabular}

Based on the analysis which was performed, the average score obtained by students was 87,06 . It shows that in general, they experienced significant improvement so that the media could bring impact the learning process. In addition, the learning result was analyzed using T-test to identify the resulting improvement after the implementation of the teaching material in the learning process.

Table 2. T-test One-Sample Test

\begin{tabular}{lcccc}
\hline & $\mathbf{t}$ & $\begin{array}{c}\text { Sig. } \\
(2-t a i l e d)\end{array}$ & Criteria & Decision \\
\hline $\begin{array}{l}\text { Learning } \\
\text { Result }\end{array}$ & 50,160 & 0,000 & $\mathrm{t}_{\text {hitung }}>\mathrm{t}_{\text {tabel }}$ & Ho was refused \\
\hline
\end{tabular}


Tabel 2 shows that based on the test which was performed, the t-test of equal variances assumed post-test was 50,161 with the $t_{\text {table }}=2,042$. Therefore, the $t_{\text {count }}>t_{\text {table }}$ meaning the $\mathrm{H} 0$ was rejected. It can be concluded that the average score of students' learning results experienced improvement after the implementation of teaching material orienting on problem-solving learning. That is why it can be generally stated that the implementation of the teaching material is effective to improve the learning results. Besides the results of the data analysis above, the difference of students' learning improvement after the implementation of the teaching material in the learning process according to $\mathrm{N}$ gain test can be also presented (Table 3 ).

Table 3. N Gain test of Pretest and Posttest Scores

\begin{tabular}{lccc}
\hline \multicolumn{1}{c}{ Class } & \multicolumn{3}{c}{ Experimental } \\
\hline $\begin{array}{l}\text { Criteria } \\
\text { The number } \\
\text { students }\end{array}$ & Low & Medium & High \\
Percentage (\%) & 0 & 1 & 20 \\
\hline
\end{tabular}

Based on the data above, there was no student in the low category. There were 11 students or $35.48 \%$ were in the high category while the majority of them (20 students) were in the high category. All in all, most of them got a very satisfying result.

\section{Discussion}

Analysis of findings presented above shows that the learning targets were successfully achieved. It is indicated by the result of the validation test performed on the media which showed that it is valid, practical, and effective. The validity test was performed by two validators and both of them put the media into Good category $(3,62)$. This shows that in terms of some components assessed and measured in the validation process, the teaching media has been feasible to use in the learning process. Nugraha and Binadja, (2013) explain that the development of a teaching media is highly affected by its quality according to the evaluation performed by experts. It aims to know how well the teaching media has fulfilled some criteria to be measured. Tegeh and Kirna, (2013) also state that the utilization of teaching media in the classroom also has a big possibility to enable students to improve their learning achievement considering that the experts of teaching design and media stated that the material has got a good qualification. Therefore, the teaching media which was developed has the potential to bring positive impacts after implemented.

In this study, students' scores in the medium and high categories experienced significant improvement. In the former group, there were 11 students or $35.48 \%$ while in the latter, there were 20 students or $64,52 \%$. In the score categorization, students were generally at a satisfying level. However, based on the learning result, there were still some students achieving a low result. It was mainly because those students found it difficult to analyze each information provided in the teaching media that was used. Besides that, students had a low ability to express their opinion during classroom discussions. In addition, referring to the average score of descriptive analysis (87,06, students obtained better scores than before. This is in line with a study conducted by Shui, et al. (2009) which indicate that there is a synergy between students' ability in learning activities and their high learning achievement. Also, the improvement of students' motivation to learn and their achievement contribute to students' performance when following the learning activities which in general showed positive conditions when doing discussion in the classroom. 
On the other hand, Hanin, et al. (2011) \& Kahar (2017) also state that the significant learning result improvement will also bring impact on individuals' development because it will be followed by students' motivation to learn. Related to the aspect of learning result improvement, students in general experienced improvement in their learning result after the delivery of developed teaching material as indicated by the the t-test $=50,160$ and $t$ table $=2,042$ with the significance level of 0,000. In line with that, Hernawan, et al. (2012) \& Serevina (2018) explain that the teaching process using teaching material can facilitate students to get more learning experiences. Learning experiences are related to a substance that will be delivered. Therefore, to obtain learning experience, teachers should design a teaching model or teaching materials to keep the effectiveness of activities in the classroom.

Soenarno (2019) mention the giving award in teaching can motivate and increase students' spirit to learn. Then, the improvement of students' knowledge is expected to contribute to their understanding of the subject that is being taught. Kahar, (2017) said that students' interest and motivation to learn highly depend on the ability of educators to manage the class and implement methods, media, and model of teaching which are suitable with the topic delivered in the classroom. Also, Kahar (2018) argued that learning design and strategy are highly determined by how well teachers utilize teaching media in the classroom and it influences the quality of teaching they carry out.

Chandra \& Watters (2012) state that teaching Physics has a correlation with the environment so that the teaching model or strategy should emphasize problem - solving approaches including ICT based strategy. The implementation of the media or the model is expected to improve students' attitude in following the class. Mihardi (2015) explain that the development of a teaching model can provide meaningful learning for students so that it will be beneficial for their characters and cognitive skills in learning Physics. This also can give good responses to students so that the implementation of the model to teach Physics can be more effective and meaningful.

\section{CONCLUSION}

Based on the research that was carried out to students at the Physics A Class, Department of Informatics Engineering Universitas Muhammadiyah Sorong, it can be concluded that there was a difference in the students' Physics learning results before and after the implementation of the teaching media which was developed. Besides that, the utilization of teaching material in the classroom gives a significant contribution to the improvement of students' learning results. The implication of this study is that it can boost the students' learning output to the Satisfying category. Therefore, further studies should develop a teaching material that integrates local culture and wisdom to assist students more easily understand the materials.

\section{ACKNOWLEDGMENT}

We thank the Directorate of Research and Community Service, Directorate General of Research and Development Reinforcement, Ministry of Research, Technology, and Higher Education for the 2019 research grants to conduct this Beginner Lecturer Research. 


\section{REFERENCES}

Alina, S., Dining Nika; Purnomo, Tarzan; \& Kuntjoro. (2016). The validity of worksheet about sets based mangrove ecosystem in the materials of ecosystem for senior high school in the coastal area of Surabaya. Scientific Periodical Biology Education, 5 (3), 189-193.

Arlitasari, O., Pujayanto, P., \& Budiharti, R. (2013). The development $f$ salingtemas based integrated science with the theme of biomass as renewable alternative energy sources. Physics Education Journal, 1.1.

Chandra, V., \& Watters, J. J. (2012). Re-thinking physics teaching with web-based learning. Computers \& Education, 58(1), 631-640.

Hanin, Rasit, Ismail \& Rozali. 2011. Methods of increasing learning motivation among students. Procedia Social and Behavioral Sciences 18: 138-147.

Hernawan, A. H., Permasih, H., \& Dewi, L. (2012). Development of Teaching Materials. Direktorat UPI, Bandung.

Hobri. 2009. Research and Development Methods. http.//hobri.blog.unej.ac.id (20 November 2013).

Hernawan, Asep Herry, Hj Permasih, \& Laksmi Dewi. (2012). Development of Teaching Materials. Direktorat UPI, Bandung .

Ilmiwan, Bahril. (2013). The effects of the implementation of teaching materials containing character values in direct learning model on students learning results at class XI, Senior High School 1 Bukittingi. Pillar Of Physics Education, 2 (1).

Kahar, M. S. (2017). The analysis of mathematical thinking skills of senior high school students in Sorong on high graded response model questions. Jurnal Keguruan Dan Ilmu Tarbiyah, 02(1), 11-18. https://doi.org/10.24042/tadris.v2i1.1389

Kahar, M. S. (2017). The analysis of students' interest to learn the use of cavendish measuring tool. SEJ (Science Education Journal), 1(2), 73-83.

Kahar, M. S. (2018). Analysis of learning motivation in the implementation of physics practicum. Formatif: Jurnal Ilmiah Pendidikan MIPA, 8(1).

Kahar, M. S. (2018). The development of physics teaching materials through STAD type cooperative learning. JIPF (Jurnal Ilmu Pendidikan Fisika), 2(2), 42-49.

Kuswandari, Meta, Widha Sunarno, and Supurwoko Supurwoko. (2013). The development of teaching materials of physics for senior high school using contextual approach in the material of physical quantities measurement. Jurnal Pendidikan Fisika, 1 (2).

Masitoh, I. \& Prabawanto, S. (2016). The improvement of understanding on concepts of math and mathematical and critical thinking skills of students at 5 grade in the elementary school through explorative learning. EduHumaniora | Jurnal Pendidikan Dasar Kampus Cibiru, 7 (2), 1-11.

Mihardi, S. (2015). Improving students' characters and learning outcomes through the development of character education based general physics learning model. Education, 6(21), 162-171.

Nugraha, D. A., \& Binadja, A. (2013). The development of SETS vision teaching materials of redox reaction oriented on constructivism. Journal of Innovative Science Education, 2(1).

Oktaviani, W., Gunawan, G., \& Sutrio, S. (2017). The development of contextual teaching materials of physics to improve students' conceptual mastery. Journal of Physics and Technology Education, 3 (1), 1-7.

Serevina, V. (2018). Development of e-module based on problem based learning (PBL) on heat and temperature to improve student's science process skill. Turkish Online Journal of Educational Technology-TOJET, 17(3), 26-36. 
Soenarno, S. M. (2019). Mastering of pedagogical content knowledge in students of natural sciences education. Formatif: Jurnal Ilmiah Pendidikan MIPA, 9 (2): 101-106. http://dx.doi.org/10.30998/formatif.v9i2.2813

Shui, L.F., Cheng, R.W. \& Ma, W.Y.K. (2009). Teacher and student intrinsic motivation in project-based learning. Instr Sci, 37:565-578.

Sinuraya, J., Panggabean, D. D., \& Wahyuni, I. (2018). Relationship analysis ICAREoriented students worksheet development with learning styles to improve learning outcomes. Advances in Social Sciences Research Journal, 5(9).

Sugiyono. 2008. Statistics for Research. Bandung: CV Alafabeta.

Tegeh, I. M., \& Kirna, I. M. (2013). The development of teaching materials about educational research methods with ADDIE model. Ika Journal, 11(1).

Toheri \& A. Azis. (2012). The effect of using audiovisual teaching media on students' mathematics learning results with the topic of three dimensions. Eduma, 1 (2), 4854.

Wulansari, A. D. (2014). The effectiveness of the implementation of learning methods: student teams achievement divisions and team assisted individualization. Cendekia, $12(1), 157-173$. 
Kahar \& Rahmawati. / Formatif: Jurnal Ilmiah Pendidikan MIPA 10(1), 57-66

This page intentionally left blank 